\title{
Are Oxidative Stress Biomarkers Sensitive to Environmental Concentrations of Chlorpyrifos Exposed to the Freshwater Crab, Zilchiopsis collastinensis (Decapoda; Trichodactylidae)?
}

\author{
C. L. Negro ${ }^{1,2} \cdot$ F. G. Iturburu ${ }^{3} \cdot$ J. Mendieta ${ }^{4}$ M. L. Menone ${ }^{3} \cdot$ P. Collins ${ }^{1,2}$
}

Received: 16 March 2019 / Accepted: 31 May 2019 / Published online: 15 June 2019

(c) Springer Science+Business Media, LLC, part of Springer Nature 2019

\begin{abstract}
Global trends in pesticide use can increase aquatic pollution and affect resident fisheries. Crabs exposed to organophosphate pesticides, such as chlorpyrifos, may increase production of reactive oxygen species (ROS), affecting the pro-oxidant/antioxidant balance. Zichiopsis collastinensis crabs were exposed to environmentally relevant concentrations of chlorpyrifos $\left(0.1\right.$ and $\left.0.5 \mu \mathrm{g} \mathrm{L}^{-1}\right)$. Effects on the oxidative stress enzymes catalase, superoxide dismutase, glutathione $S$-transferases, glutathione reductase, and on thiobarbituric acid reactive substances and hydrogen peroxide concentrations were evaluated at four intervals during $96 \mathrm{~h}$ exposures. Exposures caused decreased GST activity and increased $\mathrm{H}_{2} \mathrm{O}_{2}$ levels in gills. There were modifications of GST, CAT and SOD activities in the hepatopancreas after $12 \mathrm{~h}$ of exposure, and an increase of $\mathrm{H}_{2} \mathrm{O}_{2}$ levels at every exposure interval observed. The present study proved that chlorpyrifos lead to oxidative stress in $\mathrm{Z}$. collastinensis. However other enzymatic/non-enzymatic responses should be further investigated in order to be included as part of a battery of biomarkers, together with $\mathrm{H}_{2} \mathrm{O}_{2}$ levels, which is a parameter highly recommended to be taken into account.
\end{abstract}

Keywords Chlorpyrifos · Oxidative stress $\cdot$ Gills $\cdot$ Hepatopancreas $\cdot$ Crabs

Modern farming methods include the intensive use of fertilizers and pesticides to increase crop production. In grainexporting countries there is a massive and widespread use of these compounds, which consecutively reach nearby rivers and lakes (Etchegoyen et al. 2017). Chlorpyrifos, one of the most used pesticides, acts upon the pests by the inactivation of acetylcholinesterase (AChE) causing hyperstimulation of nicotinic and muscarinic receptors, disrupting neurotransmission and finally leading to death (Ghedira et al. 2009).

A well-documented effect of organophosphate pesticides such as chlorpyrifos is the increase in the oxygen

C. L. Negro

leonegro82@hotmail.com

1 INALI (CONICET-UNL), Ciudad Universitaria, 3000 Santa Fe, Argentina

2 ESS (FBCB-UNL), Ciudad Universitaria, 3000 Santa Fe, Argentina

3 IIMyC (UNMdP-CONICET), Funes 3350, 7600 Mar del Plata, Argentina

4 IIB (UNMdP-CONICET), Funes 3250, 7600 Mar del Plata, Argentina consumption of crustaceans. The increase of oxygen consumption rates, at individual or tissue levels, is a quick response and it is known to induce oxidative stress (they modify the prooxidant/antioxidant balance), as the generation of the so-called reactive oxygen species (ROS) is a consequence of the aerobic metabolism (Lushchak 2011). To prevent cell damage, aerobic organisms have developed antioxidant defense mechanisms capable of intercepting and inactivating ROS, such as the enzymes superoxide dismutase, catalase, peroxidases, and glutathione $S$-transferases (Ocampo et al. 2014).

All these molecules may act as early warning systems to be applied in biomonitoring studies, showing fast responses when organisms are exposed to natural pulses of pesticides in freshwater ecosystems. The use of native species is recommended as opposed to exotic species, as they may provide more relevant results (Van der Oost et al. 2003). Many of the current studies on crabs have exposed test organisms to chemical concentrations well above those measured in the environment. Thus, quick responses of the exposure to low chlorpyrifos concentrations, more related with those found in the environment, remain still unknown. 
In this work we evaluated the effects of two chlorpyrifos concentrations $\left(0.1\right.$ and $\left.0.5 \mu \mathrm{g} \mathrm{L}^{-1}\right)$, which are within the range of concentrations found in aquatic environments of Argentina and other countries (from 0.13 to $0.47 \mu \mathrm{g}$ $\mathrm{L}^{-1}$, and even higher; Alvarez et al. 2019; Etchegoyen et al. 2017; Schulz 2001) in enzymatic and non-enzymatic parameters related with oxidative stress in gills and hepatopancreas of the freshwater crab Zilchiopsis collastinensis. The main goal was to find quick responses that may be useful later in biomonitoring programs. The effects in six parameters related to oxidative stress; the enzymes catalase (CAT), superoxide dismutase (SOD), glutathione $S$ - transferases (GST), glutathione reductase (GR), and $\mathrm{H}_{2} \mathrm{O}_{2}$ levels and lipid peroxidation (thiobarbituric acid reactive substances-TBARS) were evaluated in the crab Z. collastinensis exposed in a time-response experimental design (12, 24, 48 and $96 \mathrm{~h}$ of exposure).

\section{Materials and methods}

\section{Test organisms and experimental design}

Zilchiopsis collastinensis adult crabs were collected on the Paraná River floodplain ( $31^{\circ} 30^{\prime} \mathrm{S}, 60^{\circ} 41^{\prime} \mathrm{W}$; Santa Fe, Argentina), away from cities and crop areas. The carapace width of the crabs used was 49.13 ( \pm 3.01$) \mathrm{mm}$. Additionally, the largest specimen was not more than 1.5 times larger than the smallest one. Crabs were maintained in laboratory for one month at $25 \pm 1^{\circ} \mathrm{C}$ with a $12: 12$ light/ darkness photoperiod, and fed with fresh fish muscle ad libitum. After acclimation, 72 crabs (the same proportion of males and females) were exposed individually to 0 (C0) $0.1(\mathrm{C} 1)$ and $0.5(\mathrm{C} 2) \mu \mathrm{g}$ chlorpyrifos $\mathrm{L}^{-1}$ in $6 \mathrm{~L}$ aquaria under the same light and temperature conditions. The pesticide used was Clorpi ${ }^{\circledR}$ (Red Surcos, Argentina), a commercial product containing $48 \%$ of chlorpyrifos, since commercial products are used in pesticide applications. No food was added during the experiment. Six individuals per treatment were extracted after 12,24, 48 and $96 \mathrm{~h}$ of exposure. Water samples were taken at initial time from every aquarium and chlorpyrifos concentrations were measured by gas chromatography fitted with a standard electron capture and flame photometric detectors, according to Goncalvez and Alpendurada (2002), with minor modifications. Pesticide solutions were renewed after $48 \mathrm{~h}$ to maintain the chlorpyrifos concentrations (only in $96 \mathrm{~h}$ exposure aquaria), although chlorpyrifos degradation time $\left(\mathrm{DT}_{50}\right)$ surpasses 80 days in distilled water (ATSDR 1997). Crabs were cryo-anaesthetized and samples of hepatopancreas and gills were taken and preserved at $-80^{\circ} \mathrm{C}$ until analysis.

\section{Biochemical parameters determinations and analysis}

For enzymatic activity measurements tissues extracts preparation was carried out according to Wiegand (2000) in ice cold phosphate buffer $0.1 \mathrm{M}, \mathrm{pH} 6.5,1 \mathrm{mM}$ ethylenediaminetetraacetic acid (EDTA), $14 \mathrm{mM}$ dithioerythritol (DTE) and glycerol $20 \%$ in an Potter-Elvehjem tissue homogenizer. After that, the homogenates were centrifuged in cold conditions $\left(4^{\circ} \mathrm{C}\right)$ at $10,000 \mathrm{~g}$ for ten minutes. The obtained supernatant of each sample was stored at $-80^{\circ} \mathrm{C}$ until enzymatic determinations. Enzymatic activities were determined by spectrophotometry using a Shimadtzu UV-210A (DOBLE-BEAM) at $25^{\circ} \mathrm{C}$. The activity of the soluble (cytosolic) glutathione- $S$-transferases (GST) was determined at $340 \mathrm{~nm}$, according to Habig et al. (1974). This reaction quantifies the conjugation rate of reduced glutathione with the substrate 1-chloro-2, 4-dinitrobenzene (CDNB). Glutathione reductase (GR) activity was measured at $340 \mathrm{~nm}$ quantifying the reduction of nicotinamide adenine dinucleotide phosphate (NADPH), according to Tanaka et al. (1994). CAT activity was assayed at $240 \mathrm{~nm}$ based on the decomposition of $\mathrm{H}_{2} \mathrm{O}_{2}$ according to Claiborne (1985), and SOD was assessed at $560 \mathrm{~nm}$ by the inhibition of nitro blue tetrazolium (NBT) reduction (Scebba et al. 1998). Total protein content in the homogenate was measured following the Bradford method (Bradford, 1976), at $595 \mathrm{~nm}$, using bovine albumin as standard protein. Enzymatic activities were expressed as nanokatals mg protein ${ }^{-1}$.

Hydrogen peroxide content $\left(\mathrm{H}_{2} \mathrm{O}_{2}\right)$ was quantified according to Bellincampi et al. (2000). Levels of $\mathrm{H}_{2} \mathrm{O}_{2}$ were assessed at $560 \mathrm{~nm}$ and calculated using a standard curve, based on the oxidation of $\mathrm{Fe}^{+2}$ by $\mathrm{H}_{2} \mathrm{O}_{2}$ followed by the reaction of $\mathrm{Fe}^{+3}$ with xylenol orange. Lipid peroxidation was determined by measuring the formation of thiobarbituric acid reactive substances (TBARs) (Oakes and Van Der Kraak 2003). The supernatant was measured spectrophotometrically (abs: $532 \mathrm{~nm}$ ). Levels of TBARS were expressed as nmol mg ${ }^{-1}$ of fresh tissue using a molar extinction coefficient of $1.56 \times 10^{5} \mathrm{M}^{-1} \mathrm{~cm}^{-1}$.

Because enzyme activities and $\mathrm{H}_{2} \mathrm{O}_{2}$ and TBARS levels did not differ within treatments between males and females, data were pooled in order to test statistical differences among treatments. Comparisons between control and exposed crabs at each time were made by one-way ANOVA followed by Tukey post hoc, after normality and variance homogeneity were verified by Shapiro-Wilk and Levene test respectively (Zar 1996).

\section{Results and Discussion}

Measured chlorpyrifos concentrations in water were $0.095 \pm 0.013(\mathrm{C} 1)$ and $0.532 \pm 0.070(\mathrm{C} 2) \mu \mathrm{g}$ chlorpyrifos $\mathrm{L}^{-1}$. Mortality of crabs was not observed throughout the 
experiment. However, the exposure to these environmentally relevant chlorpyrifos concentrations causes several effects at subcellular levels in gills and hepatopancreas, indicating an oxidative stress condition.

Activity of GST, GR, CAT and SOD in gills among control crabs remained consistent throughout the experiment. Activity of affected enzymes would be expected to be modified in gills with exposure to chlorpyrifos, but only GST activity significantly decreased at $12 \mathrm{~h}$ with exposure to $\mathrm{C} 1$ (Fig. 1). The levels of $\mathrm{H}_{2} \mathrm{O}_{2}$ were similar through the experiment in control crabs. However, there was a rapid increase in $\mathrm{H}_{2} \mathrm{O}_{2}$ levels after $12 \mathrm{~h}$ in crabs exposed to $\mathrm{C}_{1}$. After $96 \mathrm{~h}$ exposure there was an increase in $\mathrm{H}_{2} \mathrm{O}_{2}$ levels
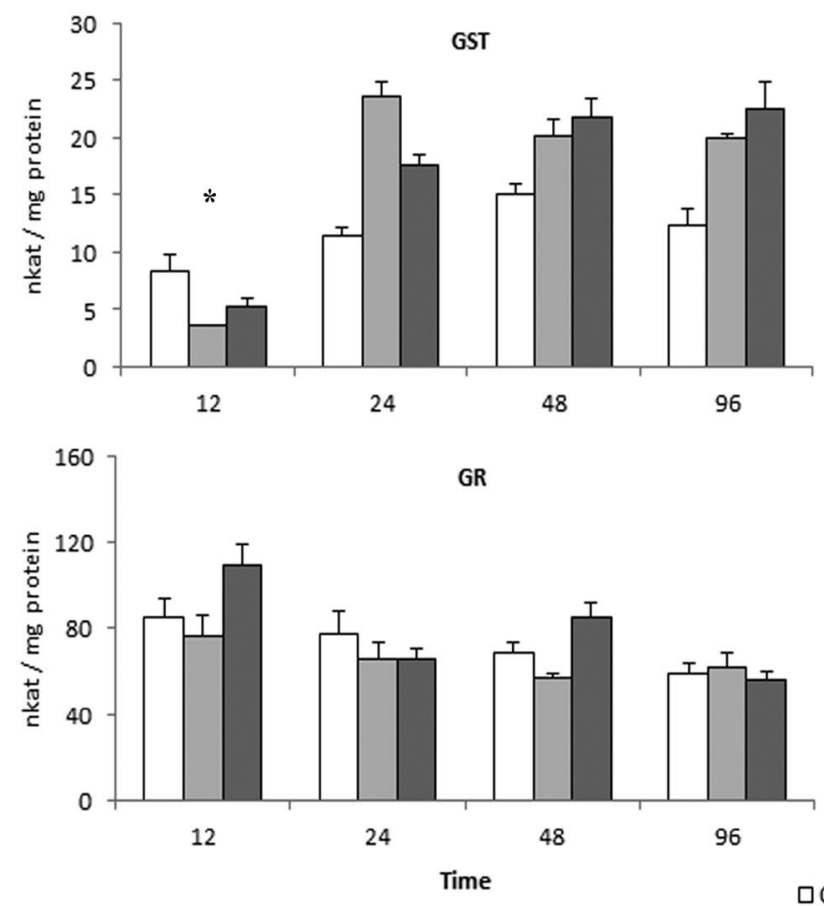

Fig. 1 Glutathione-S-transferases, glutathione reductase, catalase and superoxide dismutase activities (nkat mg protein $\left.{ }^{-1}\right)($ Mean + SE) in gills of Zilchiopsis collastinensis crabs exposed to 0.1 and $0.5 \mu \mathrm{g}$

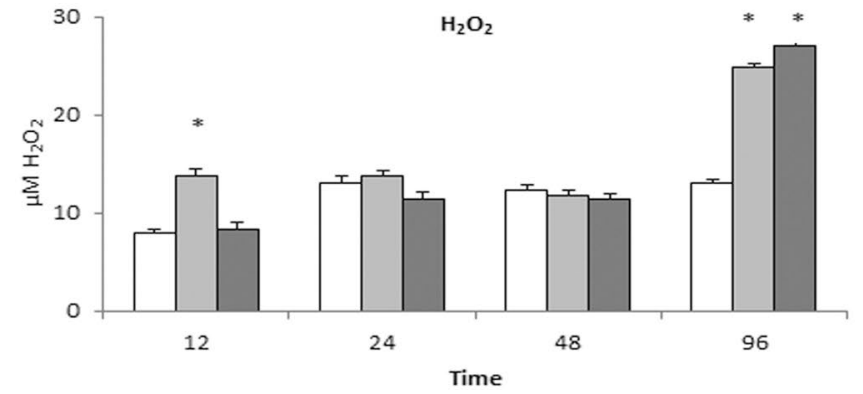

Fig. 2 Hydrogen peroxide $\left(\mathrm{H}_{2} \mathrm{O}_{2}\right)$ and thiobarbituric acid reactive substances (TBARS) levels (Mean + SE) in gills of Zilchiopsis collastinensis crabs exposed to 0.1 and $0.5 \mu \mathrm{g}$ chlorpyrifos $\mathrm{L}^{-1}$ after 12 , in gills of crabs exposed to both concentrations $(\mathrm{p}<0.05)$. The lipid peroxidation (TBARS levels) decreased in time in control crabs $(p<0.05)$, but there were no changes in exposed crabs when compared with the corresponding controls at any time ( $p>0.05)$ (Fig. 2). Gills are the first organ in contact with the pollutants present in the water. They are highly vulnerable to toxic chemicals both for their large surface area as well as gills detoxification system is not as robust as that of hepatopancreas (Abdalla et al. 2019). This could explain the general lack of enzymatic responses in $Z$. collastinensis gills acutely exposed to chlorpyirifos. We observed a rapid decrease in GST activity and an increase in $\mathrm{H}_{2} \mathrm{O}_{2}$ levels when crabs were
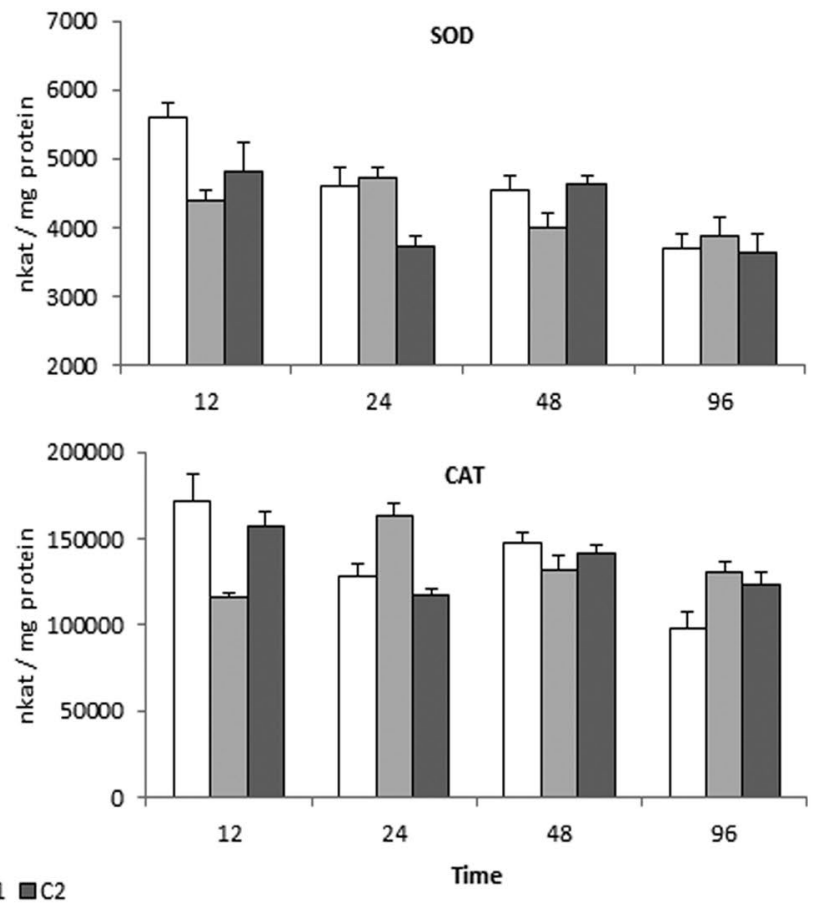

chlorpyrifos $\mathrm{L}^{-1}$ after $12,24,48$ and $96 \mathrm{~h}$ of exposure. $*=$ Statistically significant differences with their respective control group $(\mathrm{p}<0.05)$

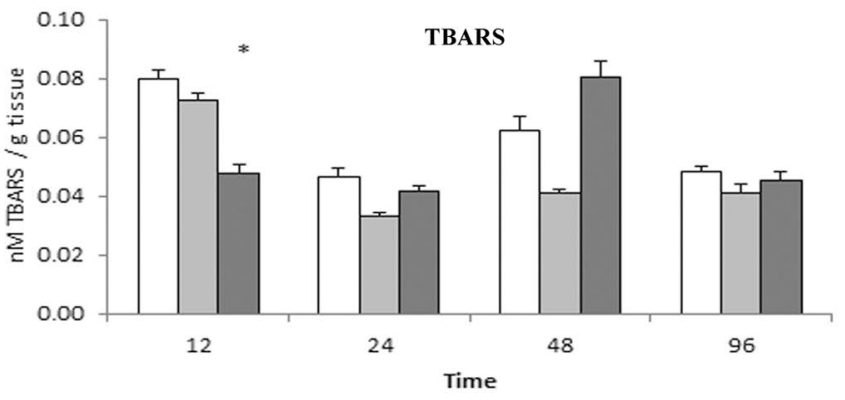

24,48 and $96 \mathrm{~h}$ of exposure. $*=$ Statistically significant differences with their respective control group $(\mathrm{p}<0.05)$ 
exposed to the low concentration, but not when they were exposed to a higher concentration. The prooxidant/antioxidant balance seems to be reached in gills in the first hours, but at the end of the exposure $\mathrm{H}_{2} \mathrm{O}_{2}$ levels were again increased. Exposure intensity and the duration of stress may modify this prooxidant/antioxidant balance by inducing the inhibition of enzymes and/or increasing the ROS production, resulting in the increase of hydrogen peroxide levels (Thomaz et al. 2009).

In hepatopancreas the GST and CAT activities were similar in control crabs through the experiment. The exposure to $0.1 \mu \mathrm{g}$ chlorpyrifos $\mathrm{L}^{-1}$ caused an increase in GST and CAT after $12 \mathrm{~h}(\mathrm{p}<0.05)$. There were no differences in GR levels among control crabs through the experiment, but an increase in GR levels in crabs exposed to $0.1 \mu \mathrm{g}$ chlorpyrifos $\mathrm{L}^{-1}$ after $48 \mathrm{~h}$ was observed. The activity of SOD did not change in control crabs, however, there was a decrease in those exposed to $0.1 \mu \mathrm{g}$ chlorpyrifos $\mathrm{L}^{-1}$ after $12 \mathrm{~h}(\mathrm{p}<0.05)$ (Fig. 3). The levels of $\mathrm{H}_{2} \mathrm{O}_{2}$ generally increased through the experiment in control crabs, but these increases were statistically significant only at 24 and $96 \mathrm{~h}(\mathrm{p}<0.05)$. Moreover, $\mathrm{H}_{2} \mathrm{O}_{2}$ levels were higher in crabs exposed to both chlorpyrifos concentrations after 12, 24, 48 and $96 \mathrm{~h}$ of exposure than in control crabs $(\mathrm{p}<0.05)$. The TBARS levels did not change in control crabs through the experiment and there were no differences between control and exposed crabs at any time (Fig. 4).
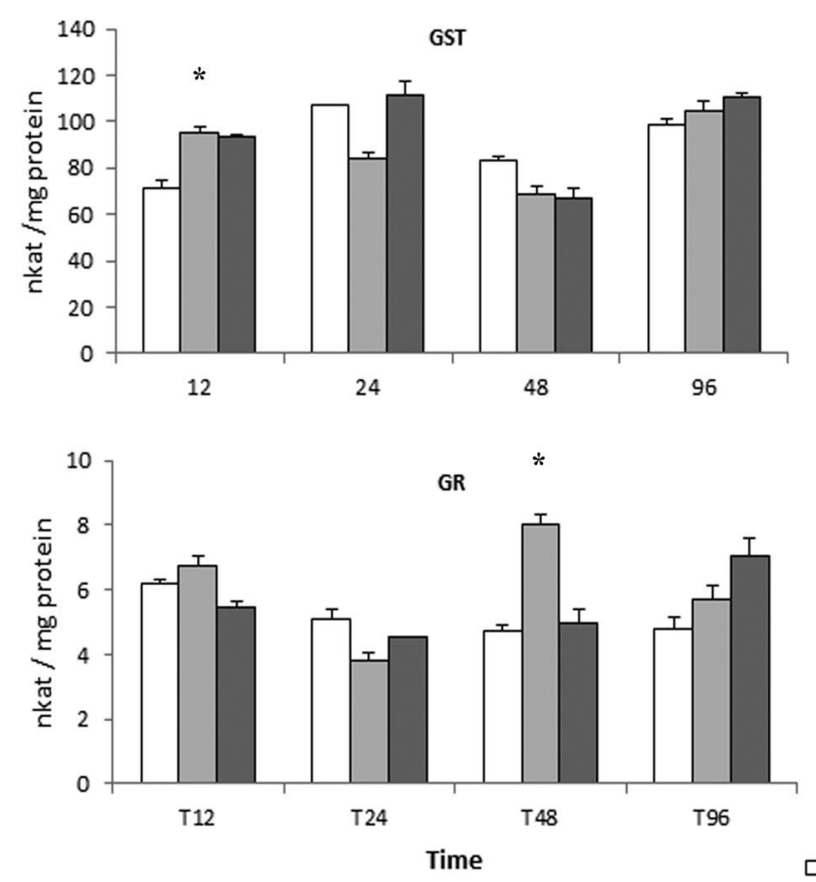

Fig. 3 Glutathione- $S$-transferases, glutathione reductase, catalase and superoxide dismutase activities (nkat mg protein $\left.{ }^{-1}\right)($ Mean $+\mathrm{SE})$ in hepatopancreas of Zilchiopsis collastinensis crabs exposed to 0.1 and
The hepatopancreas of decapod crustaceans is a dynamic organ mainly related to food digestion and storage of energy reserves. Also, this is the main organ of detoxification. The exposure of crabs to xenobiotics produces not only an increase in the general oxygen consumption but also in the oxygen consumption of hepatopancreas, as observed in the crab Neohelice granulata exposed to microcystin (Pinho et al. 2003). We hypothesized that this increase in oxygen consumption might increase ROS production, and we observed the increase of $\mathrm{H}_{2} \mathrm{O}_{2}$ from 12 to $96 \mathrm{~h}$, evidencing the oxidative stress caused by chlorpyrifos. Furthermore, after $12 \mathrm{~h}$ of exposure the antioxidant defense mechanisms were activated, which was evidenced by the increase in CAT and GST activities, although SOD activity decreased. Higher GST activities were also observed in Carcinus maenas crabs obtained from polluted sites compared with those from unpolluted areas, both in gills and hepatopancreas (digestive glands). Quick increases in CAT were also observed in the crab Charybdis japonica after the exposure to cadmium, although SOD levels also increased (Pan and Zhang 2006). According to these authors, antioxidant enzymes can increase in low concentrations of the stressor (in that case, cadmium) or short-time exposure, but decrease with time. As in our case, antioxidant enzyme activities attained a peak level in short time, suggesting an increase of ROS production and improving the ability of organisms to eliminate them. The decrease of antioxidant enzymes activities
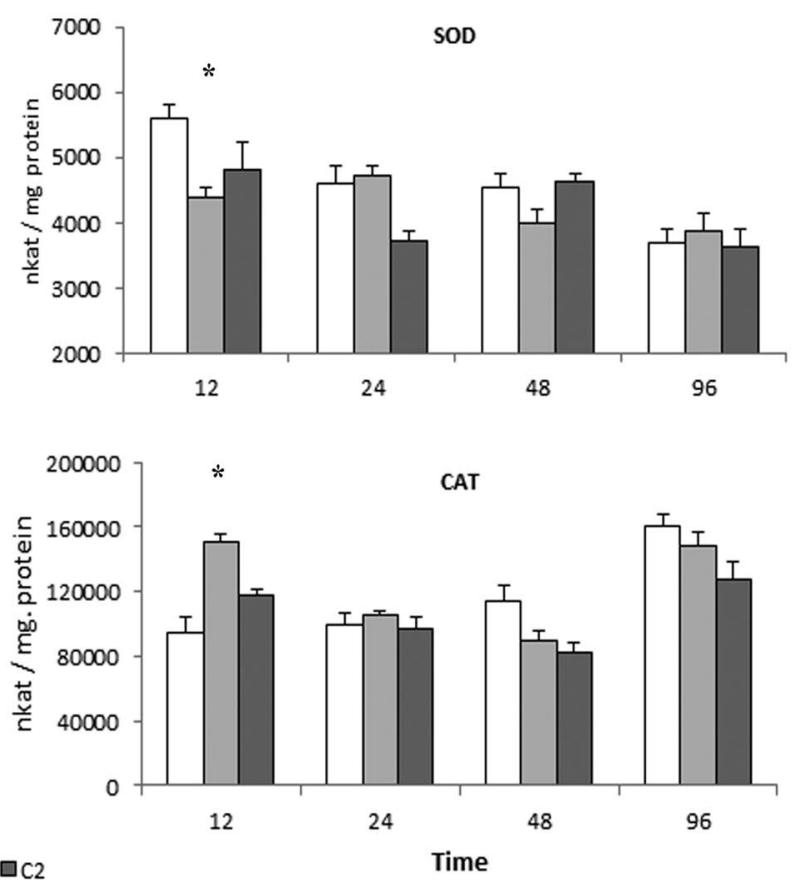

$0.5 \mu$ g chlorpyrifos $\mathrm{L}^{-1}$ after $12,24,48$ and $96 \mathrm{~h}$ of exposure. $*=$ Statistically significant differences with their respective control group $(\mathrm{p}<0.05)$ 


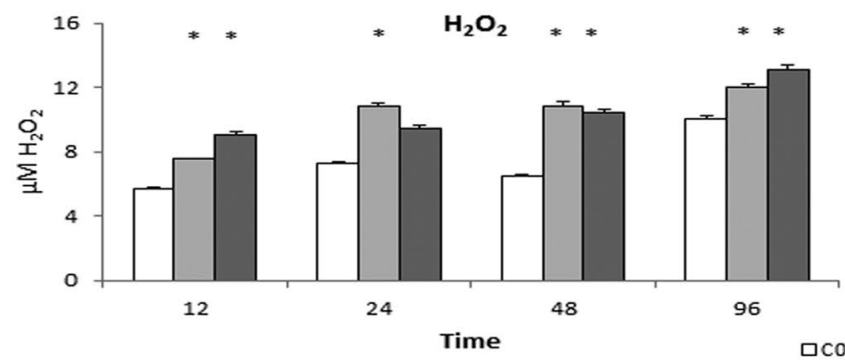

Fig. 4 Hydrogen peroxide $\left(\mathrm{H}_{2} \mathrm{O}_{2}\right)$ and thiobarbituric acid reactive substances (TBARS) levels (Mean $+\mathrm{SE}$ ) in hepatopancreas of Zilchiopsis collastinensis crabs exposed to 0.1 and $0.5 \mu \mathrm{g}$ chlorpyrifos $\mathrm{L}^{-1}$

suggested, in turn, that the organism ability to scavenge ROS was dropping (Pan and Zhang 2006).

In other crustaceans, like Daphnia magna exposed to $0.025 \mu \mathrm{g}$ chlorpyrifos $\mathrm{L}^{-1}$ for $96 \mathrm{~h}$, GST activity also increased (Ferrario et al. 2018). In the shrimp Palaemonetes argentinus exposed to $0.0945 \mu \mathrm{g}$ chlorpyrifos $\mathrm{L}^{-1}$ during $96 \mathrm{~h}$, no effects on CAT but an increase of glutathione peroxidase and decrease of GST have been reported (Bertrand et al. 2016). On the other hand, in the common yabby (Cherax destructor) exposed to $0.5 \mu \mathrm{g}$ chlorpyrifos $\mathrm{L}^{-1}$ for $96 \mathrm{~h}$, the activity of GST in hepatopancreas did not show changes with respect to a negative control (Pham et al. 2017).

However, it is noteworthy that exposure of crabs to $\mathrm{C} 2$ $\left(0.5 \mu \mathrm{g}\right.$ chlorpyrifos $\left.\mathrm{L}^{-1}\right)$ did not lead to changes in enzymatic activities in hepatopancreas (neither in gills, but this lack of response was addressed above). Two hypotheses could explain this pattern: the action of non- enzymatic antioxidant responses that were not addressed in the present work (vitamins $\mathrm{C}$ and $\mathrm{E}$, glutathione, ascorbate, urate and retinyl esters; Valavanidis et al. 2006) or the unleashing of responses at other scale (i.e. differentially expressed antioxidant genes; Li et al. 2018).

The high levels of $\mathrm{H}_{2} \mathrm{O}_{2}$ observed in the hepatopancreas were remarkable. Hydrogen peroxide is generally metabolized by CAT. Thus, if $\mathrm{H}_{2} \mathrm{O}_{2}$ levels increase, an increase in CAT activity is expected, as intent to reduce these $\mathrm{H}_{2} \mathrm{O}_{2}$ levels. However, after $24 \mathrm{~h}$ CAT activities were similar to control, denoting the breakdown of the enzyme. A general increase in $\mathrm{H}_{2} \mathrm{O}_{2}$ levels may induce lipid peroxidation which is one of the main processes induced by oxidative stress (Storey 1996). Aquatic organisms contain high amounts of lipids with polyunsaturated fatty acids residues, a substrate for oxidation by peroxides (i. e. peroxidation; Lushchak 2011). Even if increased $\mathrm{H}_{2} \mathrm{O}_{2}$ levels might increase lipid peroxidation, our results did not show this relation: observed increases in $\mathrm{H}_{2} \mathrm{O}_{2}$ levels did not have a correlate in TBARS levels. Increases in $\mathrm{H}_{2} \mathrm{O}_{2}$ levels without lipid peroxidation were also observed in $P$.

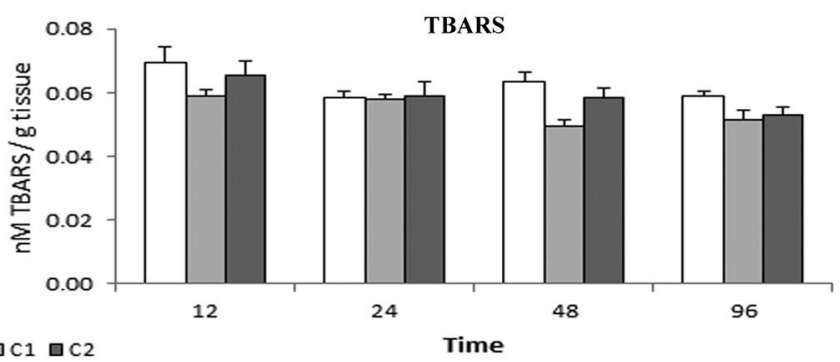

after $12,24,48$ and $96 \mathrm{~h}$ of exposure. $*=$ Statistically significant differences with their respective control group $(\mathrm{p}<0.05)$

argentinus exposed to chlorpyrifos (Bertrand et al. 2016). In another study previously reported, the exposure to chlorpyrifos caused increases in TBARS even after 1 day of exposure (Narra 2014). However, crabs were exposed to $70 \mu \mathrm{g}$ chlorpyrifos $\mathrm{L}^{-1}, 1 / 3$ of the median lethal concentration, which was significantly higher than the concentrations used in the present work and generally higher than concentrations found in the environment (Narra 2014). We hypothesize that, if a concentration of $0.1 \mu \mathrm{g}$ chlorpyrifos $\mathrm{L}^{-1}$ (plausible to be detected in the environment) maintains the observed high levels of $\mathrm{H}_{2} \mathrm{O}_{2}$ in hepatopancreas, it could lead to oxidative damage in biomolecules beyond the longest monitored time in the present study (96 h), eliciting the loss of cellular function (Del Río et al. 2005) and consequent pathological conditions as described in different organisms (Valavanidis et al. 2006).

Oxidative stress parameters in crustacean species have been used as a tool for ecotoxicological assessments. However, attention should be paid to the species used and the potential exposure concentrations, focusing always on those of environmental relevancy. Crabs of $Z$. collastinensis species could be a useful tool in biomonitoring because the sublethal concentrations modify the oxidant/antioxidant balance, mainly increasing ROS production $\left(\mathrm{H}_{2} \mathrm{O}_{2}\right.$ levels). However, other enzymatic/ non- enzymatic responses should be further investigated in order to be included as part of a battery of biomarkers, together with $\mathrm{H}_{2} \mathrm{O}_{2}$ levels, which is a parameter highly recommended to be taken into account. Finally, long term bioassays are recommended to corroborate a possible oxidative damage from a continued exposure scenario.

Acknowledgements This study was supported by the Grants PICT 20152811 and PICT 20131348 (FONCYT); (CAI + D 50020150100035LI (UNL) and EXA 795/16 (UNDMP).

\section{Compliance with Ethical Standards}

Conflict of interest The authors declare that they have no conflict of interest. 
Ethical Approval All applicable international, national, and/or institutional guidelines for the care and use of animals were followed.

\section{References}

Abdalla RP, Kida BMS, Pinheiro JPS, Oliveira LF, Martinez CBF, Moreira RG (2019) Exposure to aluminum, aluminum+ manganese and acid $\mathrm{pH}$ triggers different antioxidant responses in gills and liver of Astyanax altiparanae (Teleostei: Characiformes: Characidae) males. Comp Biochem Physiol C 215:33-40

Alvarez M, Du Mortier C, Jaureguiberry S, Venturino A (2019) Joint probabilistic analysis of risk for aquatic species and exceedance frequency for the agricultural use of chlorpyrifos in the Pampean region, Argentina. Environ Toxicol Chem. https://doi.org/10.1002/ etc. 4441 .

ATSDR, Agency for Toxic Substances and Disease Registry (1997) Toxicological profile for chlorpyrifos. ATSDR, Atlanta

Bellincampi D, Dipierro N, Salvi G, Cervone F, De Lorenzo G (2000) Extracellular $\mathrm{H}_{2} \mathrm{O}_{2}$ induced by oligogalacturonides is not involved in the inhibition of the auxin-regulated rolB gene expression in tobacco leaf explants. Plant Physiol 122:1379-1385

Bertrand L, Monferrán MV, Mouneyrac C, Bonansea RI, Asis R, Amé MV (2016) Sensitive biomarker response of the shrimp Palaemonetes argentinus exposed to chlorpyrifos at environmental concentrations: roles of alpha-tocopherol and metallothioneins. Aquat Toxicol 179:72-81

Bradford MM (1976) A rapid and sensitive method for the quantification of microgram quantities of protein utilizing the principle of protein-dye binding. Anal Biochem 72:248-254

Claiborne A (1985) Catalase activity. In: Greenwald RA (ed) Book of methods in oxygen radical research. CRC Press, Boca Raton, pp 283-284

Del Rio D, Stewart AJ, Pellegrini N (2005) A review of recent studies on malondialdehyde as toxic molecule and biological marker of oxidative stress. Nutr Metab Cardiovasc Dis 15(4):316-328

Etchegoyen MA, Ronco AE, Almada P, Abelando M, Marino DJ (2017) Occurrence and fate of pesticides in the Argentine stretch of the Paraguay-Paraná basin. Environ Monitor Assess 189:63

Ferrario C, Parolini M, De Felice B, Villa S, Finizio A (2018) Linking sub-individual and supra-individual effects in Daphnia magna exposed to sub-lethal concentration of chlorpyrifos. Environ Pollut 235:411-418

Ghedira J, Jebali J, Bouraoui Z, Banni M, Chouba L, Boussetta H (2009) Acute effects of chlorpyrifos-ethyl and secondary treated effluents on acetylcholinesterase and butyrylcholinesterase activities in Carcinus maenas. J Environ Sci 21:1467-1472

Goncalvez C, Alpendurada MF (2002) Multiresidue method for the simultaneous determination of four groups of pesticides in ground and drinking waters, using solid phase microextraction-gas chromatography with electron-capture and thermionic specific detection. J Chromatogr A 968:177-190

Habig WH, Pabst MJ, Jakoby WB (1974) Glutathione S transferases. The first step in mercapturic acid formation. J Biol Chem 249:7130-7139

Li Y, Zhou F, Huang J, Yang L, Jiang S, Yang Q, He J, Jiang S (2018) Transcriptome reveals involvement of immune defense, oxidative imbalance, and apoptosis in ammonia-stress response of the black tiger shrimp (Penaeus monodon). Fish Shellfish Immunol $83: 162-170$

Lushchak VI (2011) Environmentally induced oxidative stress in aquatic animals. Aquat Toxicol 101:13-30

Narra MR (2014) Tissue-specific recovery of oxidative and antioxidant effects of chlorpyrifos in the freshwater crab, Barytelphusa guerini. Arch Environ Contam Toxicol 67(2):158-166

Oakes KD, Van Del Kraak GJ (2003) Utility of the TBARS assay in detecting oxidative stress in white sucker (Catostomus commersoni) populations exposed to pulp mill effluent. Aquat Toxicol 63:447-463

Ocampo EH, Menone ML, Iturburu FG, Nuñez JD, Baeza JA (2014) Effect of the endosymbiotic pea crab Calyptraeotheres garthi on the metabolic rate and oxidative status of the slipper limpet Crepidula cachimilla. Invertebr Biol 133(2):170-179

Pan LQ, Zhang HX (2006) Metallothionein, antioxidant enzymes and DNA strand breaks as biomarkers of $\mathrm{Cd}$ exposure in a marine crab, Charybdis japonica. Comp Biochem Physiol C 144:67-75

Pham B, Miranda A, Allinson G, Nugegoda D (2017) Evaluating the non-lethal effects of organophosphorus and carbamate insecticides on the yabby (Cherax destructor) using cholinesterase (AChE, BChE), Glutathione S-transferase and ATPase as biomarkers. Ecotox Environ Saf 143:283-288

Pinho GL, Moura da Rosa C, Yunes JS, Luquet CM, Bianchini A, Monserrat JM (2003) Toxic effects of microcystins in the hepatopancreas of the estuarine crab Chasmagnathus granulatus (Decapoda, Grapsidae). Compar Biochem Phisiol C 135:459-468

Scebba F, Sebastiani L, Vitagliano C (1998) Changes in activity of antioxidative enzymes in wheat (Triticum aestivum) seedlings under cold acclimation. Physiol Plantarum 104:147-752

Schulz R (2001) Rainfall-induced sediment and pesticide input from orchard into the Lourens river, Western Cape, South Africa: importance of a single event. Wat Res 35(8):1869-1876

Storey KB (1996) Oxidative stress: animal adaptations in nature. Braz J Med Biol Res 29:1715-1733

Tanaka K, Sano T, Ishizuba K, Kitta K, Kawamura Y (1994) Comparison of properties of leaf and root glutathione reductases from spinach. Physiol Plantarum 91:353-358

Thomaz JM, Martins ND, Monteiro DA, Rantin FT, Kalinin AL (2009) Cardio-respiratory function and oxidative stress biomarkers in Nile tilapia exposed to the organophosphate insecticide trichlorfon $\left(\mathrm{NEGUVON}^{\circledR}\right)$. Ecotox Environ Saf 72(5):1413-1424

Valavanidis A, Vlahogianni T, Dassenakis M, Scoullos M (2006) Molecular biomarkers of oxidative stress in aquatic organisms in relation to toxic environmental pollutants. Ecotox Environ Saf 64(2): 178-189

Van der Oost R, Beyer J, Vermeulen NPE (2003) Fish bioaccumulation and biomarkers in environmental risk assessment: a review. Environ Toxicol Pharmacol 13:57-149

Wiegand C, Pflugmacher S, Oberemm A, Steinberg C (2000) Activity development of selected detoxication enzymes during the ontogenesis of the zebrafish (Danio rerio). Int Rev Hydrobiol 85(4):413-422

Zar JH (1996) Biostatistical analysis. Prentice Hall, New York 